Clarke, P. H. (1953). J. gen. Microbiol. 8, 397-407.

\title{
Hydrogen Sulphide Production by Bacteria
}

\author{
By PATRICIA H. CLARKE \\ National Collection of Type Cultures, Colindale Avenue, London, N.W. 9
}

SUMMARY: Hydrogen sulphide production by growing cultures and non-multiplying suspensions was compared and the factors influencing the sensitivity of the tests were investigated. Cysteine hydrochloride $(0.01 \%)$ was added to Lemco broth to provide a medium with a standard source of sulphur. $\mathrm{H}_{2} \mathrm{~S}$ was detected with lead acetate papers more readily than by lead acetate agar.

Suspensions were tested with cysteine, sodium thiosulphate and sodium sulphite; the organisms investigated were mainly Bacteriaceae and seldom failed to produce $\mathrm{H}_{2} \mathrm{~S}$ from cysteine; sodium thiosulphate was less readily attacked; sodium sulphite was unsuitable for this technique. Media commonly used for testing the capacity of bacteria to produce $\mathrm{H}_{2} \mathrm{~S}$ are reviewed and the value of this test in bacterial classification discussed.

Hydrogen sulphide was one of the earliest products of bacterial decomposition to be recognized. Orlowski (1895) described $\mathrm{H}_{2} \mathrm{~S}$ production by the typhoid bacillus, and Burnet \& Weissenbach (1915) and Jordan \& Victorson (1917) in comparative studies used $\mathrm{H}_{2} \mathrm{~S}$ production to distinguish between the paratyphoid and enteritidis groups. Sasaki \& Otsuka (1912) and Bürger (1914) showed that many different species of bacteria produced $\mathrm{H}_{2} \mathrm{~S}$ from cystine but not from taurine. Tanner (1917) found that a large number of bacteria produced $\mathrm{H}_{2} \mathrm{~S}$ from peptone or cystine, and some from thiourea and thiosulphate, though none examined produced it from sulphate or sulphite. Myers (1920) and Tilley $(1923 a, b)$ found variations in $\mathrm{H}_{2} \mathrm{~S}$ production from different peptones; Tilley concluded that this was not directly related to the cystine content of the peptone. He tested media reinforced with cystine, thiosulphate, sulphite and sulphate, and concluded that a thiosulphate medium was most useful for diagnostic use. Wilson (1922-3) showed that the typhoid and paratyphoid bacteria could produce $\mathrm{H}_{2} \mathrm{~S}$ from sulphite in the presence of a fermentable carbohydrate and recommended an iron + sulphite + glucose organic medium. Tarr $(1933 a, b)$ showed that the production of $\mathrm{H}_{2} \mathrm{~S}$ from cystine and cysteine by washed suspensions of Proteus vulgaris and Chromobacterium prodigiosum was enzymic; he obtained a cell-free preparation from Proteus (Tarr, 1934). He also found that the production of $\mathrm{H}_{2} \mathrm{~S}$ by Proteus from cysteine and thiosulphate was additive and independent and therefore due to two distinct enzyme systems. The cysteine enzyme was shown to be highly specific and only attacked compounds containing the $\alpha$-amino- $\beta$-thiolcarboxylic acid structure. Desnuelle \& Fromageot (1939) obtained a cell-free enzyme preparation from Bacterium coli to which they gave the name cysteinase. This enzyme was investigated in a number of species by Desnuelle \& Fromageot (1939) and by Desnuelle, Wookey \& Fromageot (1940). Fromageot (1951) concluded that cysteinase occurs in all 
bacteria which produce $\mathrm{H}_{2} \mathrm{~S}$ from organic media, and that cystine is first reduced to cysteine.

The numerous methods used to detect $\mathrm{H}_{2} \mathrm{~S}$ production by micro-organisms vary with the source of sulphur and the metal salts used to indicate $\mathrm{H}_{2} \mathrm{~S}$ formation. Lead salts were added as indicators in the media of Burnet \& Weissenbach (1915), Jordan \& Victorson (1917), Kligler (1917), Thompson (1920-1), Morrison \& Tanner (1922), Tilley (1923a), Bailey \& Lacey (1927), Spray (1936) and Friewer \& Shaughnessy (1944). Iron was added by Wilson (1922-3), Beckwith \& Moser (1932), Levine, Vaughn, Epstein \& Anderson (1931-2), ZoBell \& Feltham (1934), Tittsler \& Sandholzer (1937), Sulkin \& Willett (1939-40) and Hajna(1945). Bismuth was used in the selective bismuth sulphite medium for the typhoid-paratyphoid group (Wilson \& Blair, 1927; Wilson, 1938) and also by Pacheco \& Mello (1932), Hunter, Feldman \& Crecelius (1937) and Hunter \& Crecelius (1938). Nickel and cobalt salts were introduced by Utermohlen \& Georgi (1940), and Beckwith \& Moser (1932) used a manganous salt medium on which $\mathrm{H}_{2} \mathrm{~S}$ producers gave pink colonies. All these metallic ions are toxic to some extent, but metal salts can also be used on strips of paper above the growing culture and lead acetate is the usual choice. Wilmet (1927) showed that his lead acetate papers could detect 1 part $\mathrm{H}_{2} \mathrm{~S}$ in 7 million of air. Sasaki \& Otsuka (1912), Tanner (1917), Myers (1920), Morrison \& Tanner (1922) and Huddleson (1929) used lead acetate paper strips, and ZoBell \& Feltham (1934), in a study of the sensitivity of methods for $\mathrm{H}_{2} \mathrm{~S}$ detection by various metal salts in relation to toxicity, concluded that lead acetate papers should be used for testing unknown cultures.

The basal medium used is usually complex, containing meat extract or peptone, and is often reinforced with an additional source of sulphur, either thiosulphate (Tilley, 1923b; Tittsler \& Sandholzer, 1937; Sulkin \& Willett, 1939-40; Hajna, 1945), cysteine (Patrick \& Werkman, 1933; Utermohlen \& Georgi, 1940), or cystine (Seeliger, 1950). Sulphite is added in the bismuth glucose sulphite agar used for the isolation of Salmonella typhi and Sal. paratyphi B (Wilson \& Blair, 1927; Wilson, 1938; Tabet, 1938; Cook, 1952), and in the bismuth medium of Hunter \& Crecelius (1938). Some media contain sugars so that fermentation tests can be carried out simultaneously (Kligler, 1918; Bailey \& Lacey, 1927; Sulkin \& Willett, 1939-40; Hajna, 1945); some are semi-solid and used for simultaneous determination of motility. Knox (1949) developed a double medium plate which could be used for testing several key biochemical reactions very rapidly. Kauffmann (1951) used a peptone meat-extract medium containing ferric chloride and gelatin for determining $\mathrm{H}_{2} \mathrm{~S}$ production and gelatin liquefaction. All these media have their uses under the conditions for which they were devised, but, as many authors have shown, the results are not strictly comparable. Discrepancies may be due to the varying sensitivities of the indicators, the ability of the test organism to attack the sulphur source, the amount of growth on a given medium, or the presence or absence of fermentable carbohydrates (Wilson, 1922-3; Heap \& Cadness, 1924-5), or other reducing substances. 
ZoBell \& Meyer (1932) found that with the Brucella group the amount of $\mathrm{H}_{2} \mathrm{~S}$ produced varied with the oxidation-reduction potential. It is probably the slow oxidation of various compounds by the air which causes some $\mathrm{H}_{2} \mathrm{~S}$ media, particularly the bismuth sulphite plate media, to deteriorate on storage. Vaughn \& Levine (1936), using a ferric citrate agar, showed that the number of $\mathrm{H}_{2} \mathrm{~S}$-positive coli-aerogenes strains was increased if the agar was decreased in concentration or omitted.

The Society of American Bacteriologists (1947) recommend for use with pure cultures test strips of lead acetate paper over a suitable broth or peptone medium containing an adequate sulphur source. The advantages of this technique are the increased sensitivity and reproducibility of results and the avoidance of any toxic effects of metallic salts in the medium. It was found in this laboratory that variable results were obtained with different batches of Lemco and peptone. The addition of $0.01 \%$ cysteine hydrochloride gave a uniform source of sulphur and clear-cut results.

Clarke \& Cowan (1952) devised a test for $\mathrm{H}_{2} \mathrm{~S}$ production from cystine as part of a scheme for testing the biochemical reactions of non-multiplying suspensions of bacteria with pure substrates. We have now modified the method and use cysteine hydrochloride instead of cystine and detect $\mathrm{H}_{2} \mathrm{~S}$ with a strip of lead acetate paper. This modified method is less sensitive to variations in cell suspension density. Many strains have been investigated for their ability to produce $\mathrm{H}_{2} \mathrm{~S}$ from cysteine without the complicating effects of medium variation and compared with the results obtained with the routine medium. A smaller number of strains has been tested with sodium thiosulphate and sodium sulphite.

\section{EXPERIMENTAL}

Organisms. Strains used in this investigation included members of the following genera: Chromobacterium, Proteus, Salmonella, Shigella and the coliaerogenes group of Bacterium.

Media. The media used for all the tests on growing cultures were: Lab Lemco ( $1 \%$ ), Evans peptone $(1 \%)$, sodium chloride $(0.5 \%)$ in water and adjusted to $\mathrm{pH} 7 \cdot 6$, or this mixture with the addition of $0.01 \%$ cysteine hydrochloride.

For the preparation of suspensions the cultures were grown on Lemco agar slopes unless otherwise described in the text. In this investigation, three to four agar slopes were used for carrying out the complete series of microtests (Clarke \& Cowan, 1952). The minimum density of suspensions should be equivalent to $10^{9}$ Bact. coli cells $/ \mathrm{ml}$.

Microtest. Earlier tests were carried out by the method described by Clarke \& Cowan (1952). The later tests and all the tests with thiosulphate and sulphite were carried out as follows: Suspension 0.04 ml., was mixed in $65 \times 10 \mathrm{~mm}$. tubes with $0 \cdot 1 \%$ cysteine hydrochloride (reaction adjusted to $\mathrm{pH} \mathrm{7.4)} 0.06 \mathrm{ml}$, phosphate buffer $(0.025 \mathrm{M}, \mathrm{pH} 6.8) 0.04 \mathrm{ml}$. A strip of lead acetate paper was held in the mouth of the tube by a cotton-wool plug. The tubes were incubated at $37^{\circ}$ either in a water-bath or an air incubator and read at intervals up to 
$24 \mathrm{hr}$. Results could usually be read after 15-30 min., but for routine tests 2 and $24 \mathrm{hr}$. readings were taken. A modification of Almy's method (Almy, 1925) was tried but proved less sensitive than the lead acetate paper method.

Buffers. For the investigation of $\mathrm{pH}$ effect on enzyme activity, Walpole's acetate buffers, Sørenson's phosphate buffers, and Clarke \& Lubs borate buffers were used.

\section{RESULTS}

Microtest with cystine and cysteine. Cystine and cysteine were compared as substrates for the microtest. Pseudomonas aeruginosa was slightly more active on cysteine, but Bact. aerogenes, Bact. dispar, Sal. enteritidis and Sal. typhimurium gave identical results after $2 \mathrm{hr}$. on both substrates. Boiled suspensions were completely negative after $24 \mathrm{hr}$.

Table 1. Comparison of broth culture and microtest methods

\begin{tabular}{|c|c|c|c|c|c|c|c|}
\hline & \multirow{2}{*}{$\begin{array}{l}\text { Total } \\
\text { no. of } \\
\text { strains } \\
\text { tested }\end{array}$} & \multicolumn{2}{|c|}{ Broth culture } & \multicolumn{2}{|c|}{$\begin{array}{c}\text { Broth }+ \text { cysteine } \\
\text { culture } \\
\mathrm{H}_{2} \mathrm{~S} \text { production }\end{array}$} & \multicolumn{2}{|c|}{$\begin{array}{c}\text { Microtest + } \\
\text { cysteine }\end{array}$} \\
\hline & & + & - & + & - & + & - \\
\hline Salmonella spp. & 151 & 34 & $4 *$ & 112 & $1 \dagger$ & 151 & $\mathbf{0}$ \\
\hline Shigella spp. & 33 & $5+$ & 20 & $\mathbf{3}$ & 5 & 25 & 8 \\
\hline Bact. aerogenes & 22 & $\mathbf{3}$ & 0 & 19 & 0 & 22 & 0 \\
\hline Bact. cloacae & 3 & $\mathbf{1}$ & $\mathbf{0}$ & 2 & $\mathbf{0}$ & $\mathbf{3}$ & 0 \\
\hline Bact. coli & 85 & 4 & $\mathbf{5}$ & $75 \S$ & 1 & 85 & o \\
\hline Bact. intermedium & 43 & 1 & 1 & 40 & 1 & 43 & 0 \\
\hline Bact. pneumoniae & 18 & $\mathbf{3}$ & 3 & $9 \|$ & 3 & 18 & $\mathbf{0}$ \\
\hline Bact. rhinoscleromatis & $\mathbf{5}$ & 0 & 1 & 2 & 2 & $\mathbf{3}$ & 2 \\
\hline Bact. alcaligenes & 9 & $\mathbf{0}$ & 2 & 3 & 4 & $\mathbf{3}$ & 6 \\
\hline Paracolon group & 36 & 11 & 5 & 19 & 1 & 34 & 2 \\
\hline Proteus spp. & 44 & 0 & 0 & 44 & 0 & 44 & 0 \\
\hline Pseudomonas spp. & 4 & 1 & 2 & 1 & 0 & $\mathbf{3 \top}$ & 1 \\
\hline Chromobacterium spp. & 9 & 3 & 0 & 4 & 2 & 9 & 0 \\
\hline $\begin{array}{l}\text { * Sal. paratyph } \\
\dagger \text { Sal. paratyph } \\
+ \text { Many of the } \\
\S \text { Two cultures } \\
\| \text { Three weak p } \\
\text { I Weak positiv } \\
\text { Results are give } \\
\text { Broth tests read }\end{array}$ & $\begin{array}{l}3 \text { strains, } \\
1 \text { strain. } \\
\text { sults wit } \\
\text { able on b } \\
\text { ves. } \\
\text { ther on } b \\
\text { to } 7 \text { day }\end{array}$ & $\begin{array}{l}\text { Salm. } \\
\text { h Shige } \\
\text { roth w }\end{array}$ & $\begin{array}{l}\text { phisuis } \\
\text { spp. } \\
\text { nout cy }\end{array}$ & $\begin{array}{l}1 \text { strai } \\
\text { were slo } \\
\text { steine. }\end{array}$ & both & ests. & \\
\hline
\end{tabular}

Comparison of broth and microtest methods. Table 1 gives the results of microtest and broth culture methods. For cultures tested on both media only the broth + cysteine result is included. It will be seen that few cultures failed to produce $\mathrm{H}_{2} \mathrm{~S}$ from cysteine--some shigellas, alcaligenes, and paracolons. The Salmonella species negative on broth, including Sal. paratyphi A and Sal. choleraesuis, gave strong $\mathrm{H}_{2} \mathrm{~S}$ reactions in less than an hour in the microtest. Sal. choleraesuis, NCTC 5735, did not produce $\mathrm{H}_{2} \mathrm{~S}$ from broth or from broth $+0.01 \%$ methionine, but gave a weak positive reaction from broth $+0.01 \%$ cysteine in $24 \mathrm{hr}$. This culture was also tested on lead acetate agar containing $0.1 \%$ cysteine with a lead acetate paper above (Table 2). 
There was no blackening of the agar in $24 \mathrm{hr}$. in this test, but the lead acetate paper above turned black. This was an interesting indication of the greater sensitivity of the paper method.

Table 2. Comparison of methods for detecting $\mathbf{H}_{2} \mathbf{S}$ production

NCTC 5737

NCTC $5735 \quad$ Sal. choleraesuis Sal. choleraesuis var. kunzendorf

Method

1. Lead acetate agar

2. Lead acetate agar $+0.1 \%$ cysteine

3. Lead acetate paper over medium 2

4. Lead acetate paper over Lemco broth

5. Lead acetate paper over Lemco broth + $0.01 \%$ cysteine

6. Lead acetate paper over Lemco broth + $0.01 \%$ methionine

7. Microtest with cysteine Result after 24, hr.

\section{Production of $\mathrm{H}_{2} \mathrm{~S}$ from sodium thiosulphate}

Sodium thiosulphate is attacked by many bacteria with the production of $\mathrm{H}_{2} \mathrm{~S}$. Microtests for $\mathrm{H}_{2} \mathrm{~S}$ production from sodium thiosulphate using $1 \%$ $\mathrm{Na}_{2} \mathrm{~S}_{2} \mathrm{O}_{3}$ at $\mathrm{pH} 6 \cdot 8$ were run in parallel with the cysteine microtests (Table 3 ). The reaction was rather slower than with cysteine, blackening being first observed after 2-4 hr. Some of the negative strains were retested at $\mathrm{pH} \mathbf{7 \cdot 5}$ or 7.9 and gave slight blackening between 4 and $24 \mathrm{hr}$. In the routine test most of the strains were positive, though the reaction was usually weaker than with cysteine. The negative Salmonella species were Sal. gallinarum, Sal.

Table 3. Comparison of $\mathrm{H}_{2} \mathrm{~S}$ production from cysteine and thiosulphate

$0.04 \mathrm{ml} .0 .1 \%$ cysteine hydrochloride or $1.0 \%$ sodium thiosulphate, $0.04 \mathrm{ml} . \mathbf{0 . 2 5} \mathrm{M}$ phosphate buffer pH 6.8 and $0.04 \mathrm{ml}$. suspension. Tests read up to $24 \mathrm{hr}$.

\begin{tabular}{|c|c|c|c|c|c|}
\hline & \multirow{2}{*}{$\begin{array}{l}\text { Total no. } \\
\text { of strains } \\
\text { tested }\end{array}$} & \multicolumn{2}{|c|}{$\begin{array}{l}\text { Microtest with } \\
\text { cysteine }\end{array}$} & \multicolumn{2}{|c|}{$\begin{array}{l}\text { Microtest with } \\
\text { thiosulphate }\end{array}$} \\
\hline & & + & - & + & - \\
\hline Salmonella spp. & 60 & 60 & 0 & 52 & 8* \\
\hline Shigella spp. & 19 & 18 & 1 & 6 & $13 \dagger$ \\
\hline Bact. aerogenes & 7 & 7 & 0 & 7 & 0 \\
\hline Bact. cloacae & 2 & 2 & 0 & 1 & 1 \\
\hline Bact. coli & $7 \%$ & 77 & 0 & 63 & 14 \\
\hline Bact. intermedium & 3 & $\mathbf{3}$ & 0 & 2 & 1 \\
\hline Paracolon group & 18 & 18 & 0 & 15 & 3 \\
\hline Pr. mirabilis & 16 & 16 & 0 & 15 & 1 \\
\hline Pr. morganii & 19 & 19 & 0 & $13 \ddagger$ & 6 \\
\hline Pr. rettgeri & 6 & 6 & $\mathbf{0}$ & 0 & 6 \\
\hline Pseudomonas spp. & 3 & 2 & 1 & 0 & 3 \\
\hline Chromobacterium spp. & 6 & 6 & 0 & $5 \$$ & 1 \\
\hline
\end{tabular}

* Two strains retested at $\mathrm{pH} 7.5$ positive.

$\dagger$ Seven strains gave weak positive reactions 24 hr. at $\mathrm{pH} 7 \cdot \mathbf{5}$.

$\ddagger$ Three weak positives.

$\S$ Two weak positives. 
lexington, Sal. paratyphi A, Sal. potsdam, Sal. pullorum, and one strain each of Sal. typhi, Sal. paratyphi B and Sal. typhisuis. The two last were positive when retested at $\mathrm{pH} 7 \cdot 5$. Seven of the thirteen negative Shigella strains were weakly positive on retesting at $\mathrm{pH} 7 \cdot 5$. Of the Proteus strains none of the Pr. rettgeri produced $\mathrm{H}_{2} \mathrm{~S}$ from thiosulphate at either $\mathrm{pH} 6 \cdot 8$ or $\mathrm{pH} 7 \cdot 5$. Negative results with thiosulphate may only mean that the limit of sensitivity of this test has been reached, and not that the organism is incapable of attacking thiosulphate.

\section{Production of $\mathrm{H}_{2} \mathrm{~S}$ from sodium sulphite}

Sodium sulphite was also tested in a concentration of $1 \%$ at $\mathrm{pH} 6.8$ or $7 \cdot 5$; few organisms produced more than traces of blackening in these tests, and it was not included in the routine series. The reaction was slower than with cysteine or thiosulphate, and blackening was seldom observed before $4 \mathrm{hr}$. and not until $24 \mathrm{hr}$. with most positive strains. The addition of glucose (Wilson, 1922-3) either to the medium on which the organism was grown or to the substrate made no difference to the results. Table 4 gives the results for the strains tested on cysteine, thiosulphate and sulphite. Strains negative with thiosulphate were never positive with sulphite.

Table 4. Comparison of $\mathrm{H}_{2} \mathrm{~S}$ production from cysteine, thiosulphate and sulphite

$0.04 \mathrm{ml} .0 .1 \%$ cysteine hydrochloride or $1.0 \%$ sodium thiosulphate or $1 \%$ sodium sulphite, $0.04 \mathrm{ml}$. $0.25 \mathrm{M}$-phosphate buffer $\mathrm{pH} 6.8$ and $0.04 \mathrm{ml}$. suspension. Tests read up to $24 \mathrm{hr}$.

Salmonella spp.

Shigella spp.

Bact. coli

Proteus spp.

Pseudomonas spp.

Chromobacterium spp.

\begin{tabular}{ccc}
$\begin{array}{c}\text { Total } \\
\text { no. of } \\
\text { strains } \\
\text { tested }\end{array}$ & \multicolumn{2}{c}{$\begin{array}{c}\text { Microtest with } \\
\text { cysteine }\end{array}$} \\
\cline { 2 - 3 } 12 & + & - \\
11 & 11 & 0 \\
7 & 7 & 0 \\
9 & 9 & 0 \\
3 & 2 & 1 \\
6 & 6 & 0
\end{tabular}

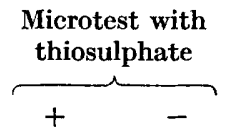

$10+2$

$7+4$

$6+1$

54

0 3

51

\begin{tabular}{|c|c|}
\hline \multicolumn{2}{|c|}{$\begin{array}{l}\text { Microtest with } \\
\text { sulphite }\end{array}$} \\
\hline$t^{*}$ & - \\
\hline 5 & 7 \\
\hline $4 \S$ & 7 \\
\hline 2 & 5 \\
\hline 0 & 9 \\
\hline 0 & 3 \\
\hline 3 & 3 \\
\hline
\end{tabular}

* Most of the positive reactions were weak.

$\dagger$ Two variable.

$\ddagger$ Six variable.

\& Two variable.

If All Pr. rettgeri.

$\mathrm{pH}$ effect. There appears to be no well-defined $\mathrm{pH}$ optimum for these reactions under the conditions of test described above. Quantitative experiments were not carried out, but a rough estimate of activity was made by assigning arbitrary values to the degree of blackening of the lead acetate papers. Bact. coli, Pr. morganii, Sal. choleraesuis and Sal. choleraesuis var. kunzendorf were tested at $\mathrm{pH}$ values between $4 \cdot 2$ and $\mathbf{9 \cdot 0}$, with the results shown in Table 5.

Adaptation. Tarr (1933b) showed that the amount of enzyme in the washed suspensions was increased when cysteine was added to the medium on which the 
cultures were grown, and that before $\mathrm{H}_{2} \mathrm{~S}$ was produced there was a lag period which could be eliminated by leaving the cells in contact with cysteine for some time or by growing the cells on cysteine reinforced agar. Desnuelle \& Fromageot (1939) observed the same effect with Bact. coli and also found that the lag period was decreased in the presence of glucose. This effect was not directly investigated, but experiments were carried out to discover the effect on the microtests of suspensions from cultures grown on nutrient agar, glucose agar, and nutrient agar containing the test substrate. The nutrient agar used must have served as an adequate cysteine source for enzyme formation, as the activity of the suspensions from cysteine-reinforced agar was not increased. Most organisms produced blackening in 15-30 min. in the microtest. Growth on glucose agar or the addition of glucose to the reaction mixture made no appreciable difference.

\section{Table 5. Effect of $\mathrm{pH}$ on $\mathrm{H}_{2} \mathrm{~S}$ production in microtest}

Numbers $=$ arbitrary values assigned to degree of blackening of lead acetate paper at $2 \mathrm{hr}$. Numbers in brackets $=24 \mathrm{hr}$. reading where $2 \mathrm{hr}$. reading was negative.

\begin{tabular}{|c|c|c|c|c|c|c|c|c|c|c|c|c|}
\hline \multirow[b]{2}{*}{ Culture } & \multirow[b]{2}{*}{ Substrate } & \multicolumn{11}{|c|}{$\mathrm{pH}$ values } \\
\hline & & $4 \cdot 2$ & $4 \cdot 7$ & $5 \cdot 0$ & $5 \cdot 6$ & $6 \cdot 2$ & $6 \cdot 8$ & $7 \cdot 2$ & $7 \cdot 8$ & $8 \cdot 1$ & $8 \cdot 5$ & $9 \cdot 0$ \\
\hline & & \multicolumn{11}{|c|}{ degree of blackening } \\
\hline \multirow{3}{*}{$\begin{array}{l}\text { Bact. coli, } \\
\text { NCTC } 86\end{array}$} & Cysteine & 3 & 3 & 4 & 4 & 5 & 4 & 4 & 4 & 5 & 5 & 4 \\
\hline & $\mathrm{Na}_{2} \mathrm{~S}_{2} \mathrm{O}_{3}$ & - & 1 & 2 & 2 & 2 & 2 & 2 & 2 & 1 & 1 & - \\
\hline & $\mathrm{Na}_{2} \mathrm{SO}_{3}$ & - & - & - & - & - & 一 & 1 & 2 & - & - & - \\
\hline \multirow{3}{*}{$\begin{array}{c}\text { Pr. morganii } \\
\text { NCTC } 235\end{array}$} & Cysteine & 1 & 3 & 4 & 6 & 6 & 6 & 6 & 6 & 6 & 6 & 6 \\
\hline & $\mathrm{Na}_{2} \mathrm{~S}_{2} \mathrm{O}_{3}$ & - & 一 & 1 & 1 & - & 一 & 一 & - & - & - & 一 \\
\hline & $\mathrm{Na}_{2} \mathrm{SO}_{3}$ & - & - & - & - & - & - & - & - & - & - & - \\
\hline \multirow{3}{*}{$\begin{array}{l}\text { Sal. cholerae- } \\
\text { suis, } \\
\text { NCTC } 5735\end{array}$} & Cysteine & - & - & - & 1 & 2 & 2 & 3 & 3 & 2 & 1 & 1 \\
\hline & $\mathrm{Na}_{2} \mathrm{~S}_{2} \mathrm{O}_{3}$ & (2) & (2) & (2) & (2) & (2) & (2) & - & 一 & - & - & - \\
\hline & $\mathrm{Na}_{2} \mathrm{SO}_{3}$ & - & - & - & - & - & - & - & - & - & - & - \\
\hline \multirow{3}{*}{$\begin{array}{l}\text { Sal. cholerae- } \\
\text { suis var. } \\
\text { kunzendorf, }\end{array}$} & Cysteine & 1 & 1 & 2 & 2 & $\mathbf{3}$ & 3 & 4 & $\mathbf{2}$ & 2 & 1 & 1 \\
\hline & $\mathrm{Na}_{2} \mathrm{~S}_{2} \mathrm{O}_{3}$ & (3) & (3) & (3) & (4) & (4) & (4) & (4) & (3) & (2) & (3) & (3) \\
\hline & $\mathrm{Na}_{2} \mathrm{SO}_{3}$ & - & (2) & (1) & (1) & (1) & (1) & (1) & (2) & (1) & - & - \\
\hline
\end{tabular}

Organisms grown on thiosulphate or sulphite agar showed little difference from control suspensions in their ability to attack these substrates, although this might have been shown if the $\mathrm{H}_{2} \mathrm{~S}$ had been estimated quantitatively. Occasionally suspensions from the reinforced agars appeared to give slightly faster and deeper blackening, but the effect was not consistent or very marked. One strain of each of the following organisms, Bact. coli, Chr. prodigiosum, Pr. morganii, Pr. mirabilis, Sal. typhi, Sal. paratyphi B, Sh. boydii and Sh. flexneri, was grown on nutrient agar, thiosulphate agar, and sulphite agar. Table 6 gives a typical result with $\boldsymbol{B}$ act. coli on the three substrates.

\section{DISCUSSION}

It is clear from the conflicting results in the literature that the classification of organisms by their ability to produce $\mathrm{H}_{2} \mathrm{~S}$ offers many pitfalls. The results depend on the content and availability of the sulphur source, the sensitivity of the method used to detect $\mathrm{H}_{2} \mathrm{~S}$, the growth of the organism on the medium, 
Table 6. The production of $\mathrm{H}_{2} \mathrm{~S}$ by Bacterium coli, NCTC 86

\begin{tabular}{|c|c|c|c|c|c|c|c|c|c|}
\hline & \multirow{2}{*}{\multicolumn{3}{|c|}{$\begin{array}{l}\text { Microtest with } \\
\text { cysteine }\end{array}$}} & \multirow{2}{*}{\multicolumn{3}{|c|}{$\begin{array}{c}\text { Microtest with } \\
\text { thiosulphate } \\
\text { Time of reading (hr.) }\end{array}$}} & \multicolumn{3}{|c|}{$\begin{array}{l}\text { Microtest with } \\
\text { sulphite }\end{array}$} \\
\hline & & & & & & & & & \\
\hline & $\frac{1}{4}$ & 2 & 24 & $\frac{1}{4}$ & 2 & 24 & $\frac{1}{4}$ & $\mathbf{2}$ & 24 \\
\hline Suspensions & \multicolumn{9}{|c|}{ Relative degree of blackening of lead acetate paper } \\
\hline Nutrient agar & 3 & 6 & 6 & 1 & 4 & 6 & 0 & 0 & 1 \\
\hline $\begin{array}{l}5 \% \text { thiosulphate } \\
\text { agar }\end{array}$ & 1 & 4 & 6 & 0 & 1 & 4 & 0 & $\mathbf{1}$ & 2 \\
\hline $5 \%$ sulphite agar & $\mathbf{1}$ & 5 & 6 & 0 & 1 & 2 & 0 & 1 & 3 \\
\hline
\end{tabular}

as well as the ability of the organism to elaborate $\mathrm{H}_{2} \mathrm{~S}$-producing enzymes. Organisms such as Proteus which readily produce $\mathrm{H}_{2} \mathrm{~S}$ from organic media will be classified as $\mathbf{H}_{2} \mathrm{~S}$-positive with any organic medium, whereas Bact. coli will be classified as positive or negative according to the test used (Hunter \& Weiss, 1938). If we assume that cystine and cysteine are the main sulphur sources in peptone media, then positive and negative results for $\mathrm{H}_{2} \mathrm{~S}$ production on organic media might be a simple method of testing the presence or absence of a specific enzyme-cysteinase. This is apparently not the case. As early as 1912 Sasaki \& Otsuka found that a wide range of bacteria all produced $\mathrm{H}_{2} \mathrm{~S}$ from an inorganic salt medium containing cystine, whereas not all of them produced $\mathrm{H}_{2} \mathrm{~S}$ on organic media. Other authors found that the addition of cystine or cysteine to their medium made their ' $\mathrm{H}_{2} \mathrm{~S}$-negative organisms' appear positive. In this paper it has been shown that using non-multiplying suspensions with cysteine, very few of the organisms tested failed to produce enough $\mathrm{H}_{2} \mathrm{~S}$ to be detected by this test; positives included such species as Sal. paratyphi A, which is usually negative on organic media. There is, however, a quantitative variation; Shigella species were much less active and included cysteine-negative organisms which may, however, have produced amounts of $\mathrm{H}_{2} \mathrm{~S}$ below the limits of the method. With thiosulphate as a substrate the reaction appears to have rather more value in classification in that fewer organisms give positive results. Again the results are not clear-cut, and in the microtest the shigellas in particular offer an example of organisms so feebly active that they may appear positive or negative. Sulphite was not a suitable substrate for this technique, but the limited number of results obtained showed that it is less readily attacked by bacteria than either cysteine or thiosulphate.

The metal salts used as indicators of $\mathbf{H}_{2} \mathrm{~S}$ production in culture media not only vary in sensitivity but also in toxicity. Utermohlen \& Georgi (1940), using a cysteine medium, found that nearly all the organisms tested tolerated $0.0001 \mathrm{M}-\mathrm{Co}$ and $0.0005 \mathrm{M}-\mathrm{Ni}$ as indicators. This medium was very sensitive and gave a large number of positives, but $S a l$. typhi was negative, suggesting that certain of its enzyme systems were particularly sensitive to cobalt and nickel. ZoBell \& Feltham (1934) state that in classifying the Brucella group by production of $\mathrm{H}_{2} \mathrm{~S}$ on lead acetate agar there was so much difference in the 
lead toleration of different brucellas that the test became one for lead toleration rather than $\mathrm{H}_{2} \mathrm{~S}$ production. Using a Bactotryptone without added sulphur source they found that newly isolated sewage organisms were less tolerant of metallic ions than laboratory stock strains, and that $0 \cdot 2 \mathrm{~mm}-\mathrm{Pb}$, the lower limit for $\mathrm{H}_{2} \mathrm{~S}$ detection in their medium, retarded the growth of some sewage bacteria and that many more bacteria were partially suppressed by $0.5 \mathrm{~mm}$ $\mathrm{Pb}$. Iron gave a wider margin between indicating and toxic levels but was less sensitive at acid $\mathrm{pH}$. Lead acetate papers were from 10 to 100 times more sensitive than the iron, lead or bismuth media, which ZoBell \& Feltham (1934) tested. The bismuth medium developed by Hunter \& Crecelius (1938) approaches the sensitivity of the lead acetate paper test.

The various selective and differential media based on testing for $\mathrm{H}_{2} \mathrm{~S}$ production are of undoubted value for the isolation and rapid investigation of bacteria of pathological significance. The method of choice will depend on the particular investigations, and the reports should indicate the medium used. For the complete description of enzymic capacity it is clearly necessary to give details of the sulphur source and the indicator, and all statements about $\mathrm{H}_{2} \mathrm{~S}$ producing capacity of an organism are incomplete unless the conditions of test are stated.

\section{REFERENCES}

Almy, L. H. (1925). A method for the estimation of hydrogen sulfide in proteinaceous food products. J. Amer. chem. Soc. 47, 1381.

Bailey, S. F. \& LACEY, G. R. (1927). A modification of the Kligler lead acetate medium. J. Bact. 13, 183.

Beckwith, T. D. \& Moser, J. R. (1932). The reduction of sulphur containing compounds in wood pulp and paper manufacture. J. Bact. 24, 43.

BÜrger, M. (1914). Über Schwefelwasserstoffbildung aus Zystin durch Bakterien. Arch. Hyg., Berl. 82, 201.

Burnet, É. \& Weissenbach, R. J. (1915). Valeur des renseignements fournis par la culture en gélose a l'acétate de plomb, pour la différenciation des bacilles typhique, paratyphique A et paratyphique B. C.R. Soc. Biol., Paris, 78, 565.

Clarke, P. H. \& Cowan, S. T. (1952). Biochemical methods for bacteriology. J.gen. Microbiol. 6, 187.

Соок, G. T. (1952). Comparison of two modifications of bismuth-sulphite agar for the isolation and growth of Salmonella typhi and Salmonella typhimurium. J. Path. Bact. 64, 559.

Desnuelle, P. \& Fromageot, C. (1939). La décomposition anaérobie de la cystéine par Bacterium coli. Enzymologia, 6, 80.

Desnuelle, P., Wookey, E. \& Fromageot, C. (1940). Sur la dégradation anaérobie de la cystéine et de la cystine par Propionibacterium pentosaceum. Enzymologia, $8,225$.

Friewer, F. \& Shaughnessy, H. J. (1944). Lead semisolid agar, a medium for use in the identification of the enteric group of bacteria. Amer. J. clin. Path. tech. Suppl. 14, 1.

Fromageot, C. (1951). Desulfhydrases. The Enzymes, 1, pt. 2, p. 1237. New York: Academic Press Inc.

Hajna, A. A. (1945). Triple-sugar iron agar medium for the identification of the intestinal group of bacteria. J. Bact. 49,516.

Heap, H. \& CaDness, B. H. E. (1924-5). The influence of carbohydrates on hydrogen sulphide production by Bacillus aertrycke (Mutton). J. Hyg., Camb. 23, 77. 
Huddleson, I. F. (1929). The differentiation of the species of the genus Brucella. Tech. Bull. Mich. agric. Exp. Sta. no. 100.

Hunter, C. A. \& Crecelius, H. G. (1938). Hydrogen sulphide studies. I. Detection of hydrogen sulphide in cultures. J. Bact. 35, 185.

Hunter, C. A., Feldman, M. \& Crecelius, G. (1937). Detection of hydrogen sulphide in cultures. $J$. Bact. 33, 31.

Hunter, C. A. \& Weiss, J. E. (1938). Comparative studies of methods for the detection of hydrogen sulphide in the coli-aerogenes group. J. Bact. 35, 20.

JoRDAN, E. O. \& Victorson, R. (1917). Differentiation of the paratyphoid-enteritidis group. II. Lead acetate agar. J. infect. Dis. 21, 554.

Kauffmann, F. (1951). Enterobacteriaceae. Copenhagen: Ejnar Munksgaard.

Kuigler, I. J. (1917). A simple medium for the differentiation of members of the typhoid-paratyphoid group. Amer. J. publ. Hlth, 7, 1042.

KLIGLER, I. J. (1918). Modifications of culture media used in the isolation and differentiation of typhoid, dysentery, and allied bacilli. J. exp. Med. 28, 319.

KNox, R. (1949). A screening plate for the rapid identification of faecal organisms. J. Path. Bact. 61, 343.

Levine, M., Vaughn, R., Epstein, S. S. \& Anderson, D. Q. (1931-2). Some differential reactions in the colon-aerogenes group of bacteria. Proc. Soc. exp. Biol., N.Y. 29, 1022.

Morrison, L. E. \& TANNER, F. W.(1922). Studies on thermophilic bacteria. I. Aerobic thermophilic bacteria from water. J. Bact. 7, 343.

Myers, J. T. (1920). The production of hydrogen sulphide by bacteria. J. Bact. 5, 231.

OrLowski, M. A. (1895). Hydrogène sulfuré comme produit de certaines bactéries. J. med. milit. Russe, cited (1897) in Jber. Fortschr. path. Mikroorg. 11, 528.

Pacheco, G. \& Mello, J. L. (1932). Sur un procédé de détermination de l'hydrogène sulfuré dans les cultures bactériennes. C.R. Soc. Biol., Paris, 110, 131-2.

Patrick, R. \& Werkman, C. H. (1933). Bacteria fermenting xylan. Iowa St. Coll. J. Sci. 7, 407.

SASAKI, T. \& OTSUKa, I. (1912). Experimentelle Untersuchungen über die Schwefelwasserstoffentwicklung der Bakterien aus Cystin und sonstigen Schwefelverbindungen. Biochem. Z. 39, 208.

Seeliger, H. (1950). Über die Identität und Stellung des B paradysenteriae palatinense (Roelke). Z. Hyg. InfektKr. 130, 490.

Society of American Bacteniologists (1947). Manual of methods for pure culture study of bacteria. Leaflet v, p. 13. Geneva, N.Y.: Biotechnic Publications.

Spray, R. S. (1936). Semisolid media for cultivation and identification of the sporulating anaerobes. J. Bact. 32, 135.

Sulkin, S. E. \& Willett, J. C. (1939-40). A triple sugar-ferrous sulfate medium for use in identification of enteric organisms. J. Lab. clin. Med. 25, 649.

TABET, F. (1938). A modification of Wilson and Blair's bismuth medium suitable for both typhoid and paratyphoid bacilli. $J$. Path. Bact. 46, 181.

TANNER, F. W. (1917). Studies on the bacterial metabolism of sulfur. I. Formation of hydrogen sulfide from certain sulfur compounds under aerobic conditions. J. Bact. 2, 585.

TARR, H. L. A. $(1933 a)$. The anaerobic decomposition of L-cystine by washed cells of Proteus vulgaris. Biochem. J. 27, 759.

TARR, H. L. A. $(1933 b)$. The enzymic formation of hydrogen sulphide by certain heterotrophic bacteria. Biochem. J. 27, 1869.

TARR, H. L. A. (1934). The enzymic formation of hydrogen sulphide by certain heterotrophic bacteria. II. Biochem. J. 28, 192.

Thompson, L. S. (1920-21). The group of hydrogen sulphide producing bacteria. J. med. Res. 42, 383. 
Tilley, F. W. (1923a). Variations in hydrogen sulphide production by bacteria. J. Bact. 8, 115.

Tilley, F. W. $(1923 b)$. The relation between chemical composition of peptones and hydrogen sulphide production by bacteria. J. Bact. 8, 287.

Tittsler, R. P. \& Sandholzer, L. A. (1937). Advantages of peptone iron agar for the routine detection of hydrogen sulphide production. Amer. J. publ. Hlth, 27, 1240.

Utermohlen, Jun., W. P. \& Georgi, C. E. (1940). A comparison of cobalt and nickel salts with other agents for the detection of hydrogen sulfide in bacterial cultures. J. Bact. 40, 449.

VAUGHN, R. \& Levine, M. (1936). Hydrogen sulfide production as a differential test in the colon group. $J$. Bact. 31, 24.

Wilmet, M. (1927). Sur la sensibilité de quelques réactifs de l'hydrogène sulphuré gazeux. C.R. Acad. Sci., Paris, 184, 287.

WiLson, W. J. (1922-3). Reduction of sulphites by certain bacteria in media containing a fermentable carbohydrate and metallic salts. J. Hyg., Camb. 21, 392.

Wilson, W. J. (1938). Isolation of Bact. typhosum by means of bismuth sulphite medium in water and milk borne epidemics. J. Hyg., Camb. 38, 507.

Wilson, W. J. \& Blair, E. M. McV. (1927). Use of a glucose, bismuth, sulphite, iron medium for the isolation of B. typhosus and B. proteus. J. Hyg., Camb. 26, 374.

ZoBell, C. E. \& Feltham, C. B. (1934). A comparison of lead, bismuth and iron as detectors of hydrogen sulphide produced by bacteria. J. Bact. 28, 169.

ZoBell, C. E. \& Meyer, K. F. (1932). Metabolism studies on the Brucella group. V. The production of hydrogen sulphide. J. infect. Dis. 51, 91.

(Received 30 October 1952) 